\title{
Ethics of mandatory vaccination for healthcare workers
}

E Galanakis (emmgalan@med.uoc.gr) ${ }^{1}$, A Jansen², P L Lopalco², J Giesecke²

1. Department of Paediatrics and Joint Graduate Programme in Bioethics, University of Crete, Heraklion, Greece

2. European Centre for Disease Prevention and Control (ECDC), Stockholm, Sweden

Citation style for this article:

Galanakis E, Jansen A, Lopalco PL, Giesecke J. Ethics of mandatory vaccination for healthcare workers. Euro Surveill. 2013;18(45):pii=20627. Available online: http://www.eurosurveillance.org/ViewArticle.aspx?Articleld=20627

Healthcare workers (HCWs) are at increased risk of contracting infections at work and further transmitting them to colleagues and patients. Immune HCWs would be protected themselves and act as a barrier against the spread of infections and maintain healthcare delivery during outbreaks, but vaccine uptake rates in HCWs have often been low. In order to achieve adequate immunisation rates in $\mathrm{HCWs}$, mandatory vaccination policies are occasionally implemented by healthcare authorities, but such policies have raised considerable controversy. Here we review the background of this debate, analyse arguments for and against mandatory vaccination policies, and consider the principles and virtues of clinical, professional, institutional and public health ethics. We conclude that there is a moral imperative for HCWs to be immune and for healthcare institutions to ensure $\mathrm{HCW}$ vaccination, in particular for those working in settings with high-risk groups of patients. If voluntary uptake of vaccination by HCWs is not optimal, patients' welfare, public health and also the HCW's own health interests should outweigh concerns about individual autonomy: fair mandatory vaccination policies for HCWs might be acceptable. Differences in diseases, patient and HCW groups at risk and available vaccines should be taken into consideration when adopting the optimal policy.

\section{Background}

Healthcare workers (HCWs) - all persons employed in acute or long-term healthcare facilities having direct contact with patients or patient's' specimens, regardless of their employment status - are at increased risk of contracting infections and further transmitting them to colleagues and patients. Immunisation against vaccine-preventable diseases would protect HCWs themselves, act as a barrier against the spread of infections and maintain healthcare delivery during outbreaks. However, immunisation rates among HCWs have often been very low, even for highly transmissible infections such as influenza, measles, pertussis and hepatitis $B$ [1-3]. Barriers to vaccination include not only concerns about vaccine effectiveness and safety, medical contraindications, religious beliefs and conscientious objection, but also inconvenience, underestimation of the person's susceptibility to the infection and of the potential to spread it further, and belief that the disease may be mild, useful or acquired from the vaccine [4-7].

The gap between the desired level of vaccination and the reality raises the question whether voluntary uptake should be replaced by mandatory vaccination. This debate also emerges in outbreaks and pandemics, when control measures should be adopted rapidly, at a time when there is some scientific uncertainty regarding the vaccine. It should also be noted that no consensus exists on the desired vaccine uptake levels, say for influenza [6]. Mandatory policies are being increasingly adopted by healthcare institutions and public health authorities - in particular in the United States but have generated vigorous opposition [8]. Legislation on mandatory smallpox vaccination dates from 1809 in the United States and from 1840 in Britain; in 1898, the concept of 'conscientious objector' was introduced into British law for parents objecting to smallpox vaccination for their children and in 1905 the United States Supreme Court ruled that the state could not require vaccination to protect an individual, but could do so to protect the public [9].

The ethical dimensions of mandatory vaccination have been analysed adequately for seasonal influenza, less so for pandemic influenza and even less for other highly transmissible diseases (e.g. measles, pertussis, hepatitis B) or the vaccine-preventable diseases as a whole. Here we review the involvement of HCWs in the transmission of vaccine-preventable diseases and the evidence on whether HCW vaccination contributes to patients' health. It should be stressed that this evidence used in this article comes mainly from influenza studies. We also evaluate whether voluntary vaccination has failed and whether mandatory policies can achieve higher uptake rates and at what cost, present the practical and ethical arguments for and against mandatory policies, and try to draw some conclusions on the ethical rationale for implementing mandatory vaccination for HCWs. Given that this article is a perspective, we have cited only a small proportion of the numerous relevant studies. 
For which vaccine-preventable diseases is $\mathrm{HCW}$ vaccination worth considering?

Most vaccine-preventable diseases are transmissible to a greater or lesser extent and have a basic immunisation schedule in childhood. These infections differ regarding the severity of infection, risk to patients or specific HCW groups and effectiveness of the vaccine. HCWs should be expected to be immune by the time they are employed. However, for some diseases, waning immunity may call for booster doses, e.g. for pertussis. Seasonal influenza requires annual vaccination and outbreaks or pandemics may require additional administration of existing or new vaccines.

Despite the long existence of effective vaccines, vaccine-preventable diseases remain a major health threat worldwide. In the United States, mortality rates of seasonal influenza are equal to that of breast cancer and three times that of human immunodeficiency/ acquired immunodeficiency syndrome (HIV/AIDS) $[8,10]$. Measles is on the rise in Europe [3] and pertussis is also increasing in many countries worldwide [1]. Antimicrobial agents may be ineffective (e.g. for influenza where there is an issue of resistance or for pertussis) or do not exist (e.g. for measles). Hence, prevention including vaccination is of paramount importance.

Vaccine-preventable diseases may be transmitted before symptoms develop and are often subclinical, thus permitting HCWs to keep working and spreading the pathogens. Transmission involving HCWs has been reported for a variety of healthcare facilities and diseases, including seasonal and pandemic influenza, measles, mumps, rubella, varicella, pertussis, hepatitis A, hepatitis B and meningococcal invasive disease: this nosocomial transmission has led to outbreaks and deaths, and the burden for HCWs themselves has been considerable in terms of morbidity and mortality $[2,3,11-13]$.

\section{Are the effectiveness, safety}

\section{and cost-effectiveness of $\mathrm{HCW}$} vaccination documented?

Vaccines are in general highly effective, in particular when the recipients are healthy adults, as HCWs often are. Most vaccines currently in use have been given to millions of individuals and have been shown to be safe. Long debate has cleared hepatitis B and measles-mumps-rubella vaccines from alleged side effects $[14,15]$. Guillain-Barré syndrome following influenza vaccination seems to be extremely rare; narcolepsy has recently been related to the pandemic influenza $\mathrm{A}\left(\mathrm{H}_{1} \mathrm{~N}_{1}\right)$ pdmog vaccine, but this vaccine has in general been shown to be safe [16]. HCW influenza vaccination has been reported to be cost-effective [17]: this might also be true for other vaccines, through prevention of illness, absenteeism and disruption of healthcare delivery.

\section{Do patients benefit as a result of $\mathrm{HCW}$ vaccination?}

Influenza-like illness and all-cause mortality were shown to decrease in residents of long-term care facilities when HCWs were vaccinated against influenza in several studies, including four randomised controlled trials [18-21]. Vaccination of five and eight HCWs was estimated to prevent one case of influenza-like illness and death of one resident, respectively [20]. However, a recent systematic review did not provide reasonable evidence that HCW influenza vaccination affects the outcome of elderly residents (aged 60 years or older) [22]. HCW influenza vaccination has been shown to protect hospitalised patients, including bone marrow transplant recipients $[11,12]$. The impact of HCW vaccination in acute care settings is more difficult to study, as patients may have been exposed to other, nonnosocomial contacts before and after hospitalisation.

Further well-designed studies seem to be required for firm conclusions to be drawn on whether vaccinating HCWs protects patients or residents of care facilities, on the numbers of HCWs to be vaccinated in order to prevent one nosocomial infection, and on risk assessment for different groups and settings. However, further randomised, placebo-controlled studies might not be ethical, given the existing evidence and the known protection by vaccines for HCWs and patients [23,24]. Not much is known about protecting patients through vaccinating $\mathrm{HCW}$ for infections other than influenza and this lack of solid evidence should be taken into consideration when deciding on voluntary versus mandatory vaccination policies.

\section{Have voluntary vaccination policies for HCWs failed?}

\section{Annual vaccination: seasonal influenza}

Voluntary vaccination programmes for HCWs seem to have been fruitless for decades, despite consistent recommendations, dedicated efforts, vaccine availability free of charge, publicity (including posters and flyers), education, posters and flyers, incentives and rewards, buttons for vaccinated individuals to wear, and mobile vaccination teams $[10,24,25]$. Despite recommendations by the United States Centers for Disease Control and Prevention (CDC) on influenza vaccination for all HCWs since the early 1980s, uptake rates in the United States have stagnated around 40-50\% [4,7], only reaching up to $60-70 \%$ after intense promotion and sustained campaigns $[4,6,11]$. In Europe, despite recommendations since at least 2000 , uptake rates are commonly less than $35 \%$ and often less than $25 \%$ $[6,17,26]$.

\section{Basic vaccination: measles and pertussis}

Immunity against measles and pertussis may be the result of both vaccination and natural infection, and it would seem reasonable to expect $\mathrm{HCW}$ s to be highly immune. However, susceptibility rates of HCWs to measles in Europe have been found to range from 3\% to 
TABLE 1

Practical arguments for and against mandatory vaccination for healthcare workers as a means to protect patients' health

\begin{tabular}{|c|c|c|}
\hline Argument & For mandatory vaccination & Against mandatory vaccination \\
\hline Effectiveness & $\begin{array}{l}\text { Although protection is difficult to study in all } \\
\text { settings, reason and existing data support } \\
\text { benefit for patients through HCW vaccination. }\end{array}$ & $\begin{array}{l}\text { Solid evidence for patients' benefit is missing, as are risk } \\
\text { assessments for specific groups of HCWs, settings and } \\
\text { diseases. }\end{array}$ \\
\hline Necessity & $\begin{array}{l}\text { Experience has shown well that only mandatory } \\
\text { vaccination can achieve high vaccination rates. }\end{array}$ & $\begin{array}{l}\text { Voluntary vaccine uptake rates among HCWs may not be } \\
\text { high enough, but are not negligible and may become even } \\
\text { higher without a need for mandates. It is questionable } \\
\text { whether any increase by coercion would be worth the cost } \\
\text { of conflict. Regardless of HCW vaccination, patients will } \\
\text { continue to be exposed. }\end{array}$ \\
\hline False sense of security & $\begin{array}{l}\text { Over-stressing vaccination does not devalue } \\
\text { other preventive measures. HCWs should adhere } \\
\text { to all appropriate preventive measures. }\end{array}$ & $\begin{array}{l}\text { Over-stressing mandatory vaccination might create a false } \\
\text { sense of security and divert focus from other important } \\
\text { preventive measures, e.g. hygiene, standard precautions or } \\
\text { other interventions [12,23]. Studies to test this hypothesis } \\
\text { have not been performed to date [26]. }\end{array}$ \\
\hline Administrative issues & $\begin{array}{l}\text { Mandatory uptake facilitates a fair, simple and } \\
\text { uniform policy of HCW vaccination. }\end{array}$ & $\begin{array}{l}\text { Voluntary vaccination policies are closer to the principle of } \\
\text { subsidiarity than authoritarian mandates. }\end{array}$ \\
\hline Cost & $\begin{array}{l}\text { Educational programmes to promote voluntary } \\
\text { vaccination are costly and have not worked. } \\
\text { Simple mandatory policies cost less. }\end{array}$ & $\begin{array}{l}\text { Resources for enforcement and debate may be better } \\
\text { devoted to educational programmes. }\end{array}$ \\
\hline Coercion & $\begin{array}{l}\text { Rules in healthcare settings are common and } \\
\text { need not to be seen as coercion. }\end{array}$ & $\begin{array}{l}\text { Enforcement and penalties may have a long-term } \\
\text { detrimental effect on the employer-employee relationship, } \\
\text { devalue HCWs who are allies in the promotion of vaccination } \\
\text { and ultimately undermine uptake of the vaccine under } \\
\text { consideration or of other vaccines [7,32]. HCWs declining } \\
\text { vaccination have the right to expect that their opinion will } \\
\text { be respected rather than being faced with infringement of } \\
\text { the equal opportunity to work, and the challenge would be } \\
\text { in convincing rather than forcing them }[1,8] \text {. Furthermore, } \\
\text { use of coercion in HCW vaccination might suggest that } \\
\text { HCWs are reluctant to be vaccinated themselves and might } \\
\text { thus strengthen the arguments of vaccine sceptics. }\end{array}$ \\
\hline Civil liberties & $\begin{array}{l}\text { HCWs have a specific mission and obligations } \\
\text { towards the common good. }\end{array}$ & Compulsory vaccination violates civil liberties. \\
\hline Potential harm & $\begin{array}{l}\text { Considerable side effects from vaccines are } \\
\text { extremely rare. }\end{array}$ & $\begin{array}{l}\text { Any harm from the vaccination is difficult to justify with } \\
\text { mandatory policies and considerable insurance issues may } \\
\text { emerge. }\end{array}$ \\
\hline
\end{tabular}

HCW: healthcare worker.

HCWs are all persons employed in acute or long-term healthcare facilities having direct contact with patients or patients' specimens, regardless of their employment status.

$17 \%$ [27]. Low vaccination rates have been reported for the booster dose of pertussis among HCWs in France (33\%) [1] and Australia (13-23\%) [28].

\section{Pandemic influenza vaccination}

HCWs were declared by the World Health Organization (WHO), CDC and the European Union (EU) Health Security Committee as apriority group to receive the pandemic influenza $A\left(\mathrm{H}_{1} \mathrm{~N}_{1}\right)$ pdmog vaccine [29]. However, vaccine uptake rates by HCWs were not always high, ranging from $13 \%$ to $83 \%[2,5]$, compatible with the $2-82 \%$ shown for seasonal influenza in a
2005 review [6]. As with seasonal influenza, rates varied among different groups of HCWs [2].

\section{Have mandatory vaccination policies for HCWs performed well?}

Healthcare institutions often require, as a condition of employment, confirmed immunity to infections such as measles, rubella, mumps, varicella and hepatitis $B$ and tuberculosis screening, and this policy has been well accepted $[4,10,13,24]$.The first institution to make influenza vaccination a 'fitness-for-duty' condition for all HCWs seems to have been Virginia Mason Medical 
Center, Seattle, Washington, United States, effective from 2005, achieving rates of $98 \%$ [30]. Subsequent mandatory programmes in the United States have increased influenza coverage rates from $71 \%$ in 2007 to $98 \%$ in 2008 [24] and from $69 \%$ in 2009 to $96 \%$ in 2010 [25]. These policies have occasionally met intense resistance by individual $\mathrm{HCWs}$ and their associations in the United States $[6,7,24,25,31,32]$ and the promising results may not be easy to replicate in all settings or in all European countries.

\section{Enforcement of mandatory vaccination}

Enforced mandatory policies are meant to be policies with well-defined consequences for HCWs who decline, such as firing, fines, reallocation to other positions, imposing a mask or prophylactic regimens during patient care and providing different badges to non-vaccinated HCWs $[8,9,12,24,25,33]$. Firing or resignation of the HCW have been reported in the United States, with rates of $0.02 \%$ to $0.15 \%[24,26,30]$, but not in Europe [33]. Even in European countries with mandatory policies, such policies may not be fully implemented in practice [33] and it is uncertain whether HCWs have ever paid fines for non-compliance.

\section{Exemptions and declination policies}

In mandatory vaccination programmes in the United States, HCWs have retained the right to apply for exemption, usually for medical (0.2-1.9\% of all HCWs) or religious (0.1-2.4\% of all HCWs) reasons [24,25,30,34]; however, little is known about this in Europe. Issues arise on how to distinguish between legitimate and illegitimate reasons and between conscientious objectors and 'free riders' (i.e. individuals relying on the immunity of others) and on how to achieve the desired vaccine uptake if objectors form a considerable proportion of HCWs. Furthermore, overuse of exemptions on non-documented medical, religious and conscience grounds might suggest that vaccination is not really important. Disease outbreaks have occurred in areas where too many HCWs opted out [9].

Several institutions have adopted declination policies, i.e. signed statements by HCWs who object to vaccination for hepatitis B or influenza $[7,23]$. Declination statements were provided by $10.7 \%$ of the HCWs in an influenza programme in the United States National Institutes of Health Clinical Center, in 2008-09 [34].

When asked, $25-75 \%$ of HCWs in Hong Kong, United Kingdom and Singapore would agree with mandatory vaccination for pandemic influenza [5] and 59\% of nurses would agree with mandatory vaccination for seasonal influenza provided that declination would be allowed [35]. HCWs might be more likely to accept policies targeting specific groups of HCWs, such as those caring for infants or immunocompromised patients, and this seems to be a promising research field.

\section{Is mandatory vaccination} needed for HCWs?

An overview of arguments of a rather practical nature (Table 1) may elucidate important aspects of the voluntary versus mandatory vaccination debate.

\section{Improvement of voluntary uptake}

Vaccine uptake is known to be affected by modifiable factors (such as education and ease of access to vaccination) and the potential of voluntary programmes may not have been exhausted $[6,7,26]$. Voluntary vaccination policies have often had little support and multifaceted programmes have not been widely implemented [6]. Making clear to HCWs that they serve as vectors for disease transmission to their own patients seems to be a key motivation $[6,23,32]$. Sustaining declination policies and requiring institutions to report HCW vaccination rates for a series of vaccine-preventable diseases as a measure of quality of care could facilitate vaccine uptake $[19,23,33]$. However, the definition of a HCW is sometimes vague and high-risk groups should better be targeted, such as those caring for infants, elderly people and immunocompromised patients. Finally, voluntary policies respect civil liberties and the principles of subsidiarity and of least infringement [26].

\section{Is mandatory vaccination of \\ HCWs ethically justified?}

Discussion to date has often focused on the principles of clinical ethics; however, ethical arguments for and against mandatory policies are also related to professional, institutional and public health ethics [31,36]. In public health ethics, the approach often differs from that of clinical ethics. For example, autonomy is a key principle in clinical ethics, but not in public health ethics. We present how principles and virtues have been used in vaccination issues, without weighing them against each other (Table 2 ).

\section{Professional ethics: addressing professional obligations}

Healthcare professional societies have a responsibility to guide their members on decorum and the virtues of healing professions and also to meet the public's expectations. Public trust will be damaged if HCWs appear to suggest vaccines for others but avoid them for themselves $[10,26]$. Vaccination is consistent with a collective professional obligation, and being immune is a part of the responsibility of being a healer $[7,9,31]$. In general, HCWs have freely chosen their profession, and this assumes adopting professional virtues and accepting some level of personal risk in providing care. It could also be further argued that non-immune HCWs should accept being reallocated to positions without patient contact or leave the profession $[8,31,32,36]$.

Institutional ethics: the duty to protect employees and patients and keep working In addition to protecting their employees, healthcare institutions have an obligation to reduce risks to patients and residents and costs from nosocomial 
TABLE 2

Ethical arguments for and against mandatory vaccination for healthcare workers as a means to protect patients' health

\begin{tabular}{|c|c|c|}
\hline Argument & For mandatory vaccination & Against mandatory vaccination \\
\hline Autonomy & $\begin{array}{l}\text { Autonomy should be respected, but restrictions } \\
\text { of HCW autonomy might be accepted, if it is to } \\
\text { prevent harm to patients, in particular when it } \\
\text { comes to HCWs. }\end{array}$ & $\begin{array}{l}\text { Mandatory policies violate liberty and autonomy; no } \\
\text { one should be forced to take medications, in particular } \\
\text { controversial and potentially harmful as vaccines }[26,29,36] \text {. } \\
\text { Vaccination pits autonomy against non-maleficence and } \\
\text { even libertarians would more or less accept restriction of } \\
\text { individual liberties, if this could promote community health } \\
\text { [9,31,32]. }\end{array}$ \\
\hline Beneficence & $\begin{array}{l}\text { If it is feasible to benefit colleagues and } \\
\text { patients, with minimal inconvenience, then HCWs } \\
\text { are obliged to comply. }\end{array}$ & $\begin{array}{l}\text { Ensuring patients' welfare is a duty for HCWs, but it is } \\
\text { questionable whether this implies the obligation to be } \\
\text { vaccinated. The principle of beneficence should not } \\
\text { be interpreted as doing good by harming persons, i.e. } \\
\text { protecting patients by harming HCWs. HCWs should not } \\
\text { harm their patients by, say, malpractice, but should not be } \\
\text { forced to harm themselves for the sake of their patients' } \\
\text { health, as persons ought not be used as a means to good } \\
\text { ends }[26,36] \text {. If, say, influenza vaccine virus strains do } \\
\text { not match with the circulating strains, HCWs may suffer } \\
\text { unjustified harm at no benefit to patients. }\end{array}$ \\
\hline Non-maleficence & $\begin{array}{l}\text { The question of how much non-vaccinated HCWs } \\
\text { harm patients is of little importance. Any means } \\
\text { that would avoid harming patients should be } \\
\text { considered. If there is a duty for everyone not to } \\
\text { harm others by infection, this should obviously } \\
\text { apply even more so to HCWs }[4,26] \text {; of note, } \\
\text { the imperative primum non nocere (first do no } \\
\text { harm) dates back to the Hippocratic collection. } \\
\text { Vaccines may or may not be } 100 \% \text { effective } \\
\text { and studies may or may not show significant } \\
\text { protection of patients through HCW vaccination, } \\
\text { but any case of a patient contracting a vaccine-- } \\
\text { preventable diseases from a non-immune HCW } \\
\text { would be unacceptable under this tradition. }\end{array}$ & $\begin{array}{l}\text { No solid evidence exists on whether non-vaccinated HCWs } \\
\text { harm patients. Patients will continue to be exposed, } \\
\text { regardless of HCW vaccination. }\end{array}$ \\
\hline Justice & $\begin{array}{l}\text { It is unfair for patients who cannot be effectively } \\
\text { vaccinated (such as infants, elderly people } \\
\text { and those who are immunocompromised) to be } \\
\text { treated by non-immune HCWs. Such patients can } \\
\text { only be protected by cocoon strategies involving } \\
\text { immune caregivers. Justice would further require } \\
\text { that non-immune HCWs inform patients about } \\
\text { their non-immunised status [8]. } \\
\text { Resources for education of HCWs could be } \\
\text { devoted to other needs. }\end{array}$ & $\begin{array}{l}\text { Voluntary vaccination policies are closer to the principle of } \\
\text { subsidiarity than authoritarian mandates. }\end{array}$ \\
\hline Professional virtue & $\begin{array}{l}\text { The imperative 'do no harm' is a fundamental } \\
\text { virtue for health professionals. Instead of } \\
\text { insisting on autonomy, HCWs should have their } \\
\text { patients' health as their top priority. }\end{array}$ & $\begin{array}{l}\text { Good ends cannot be achieved through evil means. It is } \\
\text { immoral to enforce policies that may promote patients' } \\
\text { health through subjecting HCWs to potential harm. }\end{array}$ \\
\hline
\end{tabular}

HCW: healthcare worker.

HCWs are all persons employed in acute or long-term healthcare facilities having direct contact with patients or patients' specimens, regardless of their employment status. 


\section{FIGURE}

Proposed stepwise implementation of vaccination policies for healthcare workers upon employment and in controlling vaccine-preventable diseases

\section{Issues regarding healthcare workers}

For all employees with direct patient care:

- check immunity status (history of diseases, vaccine doses,

serology, tuberculin test)

-keep records of individual HCW immunity status

Discuss with HCWs:

- susceptibility to vaccine-preventable disease and the risk of being infected and transmitting pathogens to patients

-vaccine effectiveness, safety, procedures

- what they think the vaccination policy should be
Issues regarding vaccine under consideration

-What is the evidence that patients are at risk and protected through HCW vaccination?

-What are the desired rates of vaccine uptake?

- Should all HCWs or specific groups be targeted?

-Are there provisions for compensation in case of harm and related insurance?

-Is the expected increase of vaccine uptake by mandatory policy worth the coercion?

-Is it possible that forcing HCWs may badly affect uptake of this or other vaccines?

- Secure access to and adequate supply of vaccines

\section{$+$}

Consider the optimal policy for the specific disease, vaccine, community and setting

- The least restrictive policy should be adopted to achieve the defined vaccine uptake target

- HCWs' objections should be respected; clear opt-out criteria should be defined in a transparent manner

- For HCWs to be employed, make it clear whether and which objections would be allowed

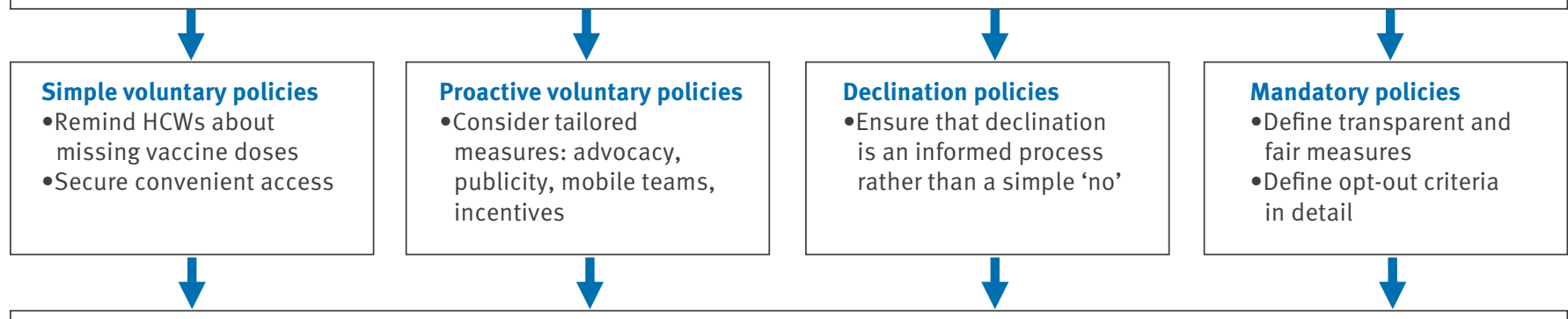

Additional measures

Regardless of policy, secure adherence of HCWs to all standard prevention measures; consider additional prevention measures for non-vaccinated HCWs

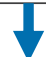

Review progress and plan next steps

- Track vaccination rates and policy success, reconsider the desired levels of immunisation

- Remind individual HCWs of any missing doses and the yearly booster of influenza vaccination

- Seek input from HCWs for improvement, e.g. through customer satisfaction surveys

- Consider changes in vaccination policy

HCW: healthcare worker.

HCWs: all persons employed in acute or long-term healthcare facilities having direct contact with patients or patients' specimens, regardless of their employment status.

Specific groups: HCW groups working with vulnerable patients, such as those in maternity wards, with young children or immunocompromised individuals, or in chronic care facilities with elderly residents.

Voluntary vaccination: vaccine uptake is a free choice of recipients. Voluntary policies may or may not be promoted through multifaceted programmes, but no one is forced to receive the vaccine.

Declination policy: HCWs wishing not to be vaccinated sign a statement declaring that they have been informed on the benefits and risks of the vaccine to themselves and to their patients.

Mandatory vaccination: there are well-defined penalties for non-compliance, such as non-employment, reallocation to low-risk positions or firing. Mandatory policies may be enforced or not enforced (measures are rather theoretical and refusals will not have a penalty in the end). 
transmission, and to remain effective during disease outbreaks. Hence, there is an imperative for institutions to achieve adequate vaccination rates among HCWs by adopting the most appropriate policy (Figure) [26].

\section{Public health ethics: control of}

disease and limits on liberty

Controlling the spread of infection is a top priority in public health [36]. Hence, when the choice is to be made between safety and liberty, limits on liberty may be justified, as the right of the community to protection seem to outweigh the right of HCWs to free decisions. Even spending resources on unsuccessful voluntary vaccination campaigns seems not to be justified, as such resources could better be used elsewhere [36].

\section{Conclusions}

It is morally justified to summon HCWs in particular to be voluntarily vaccinated, along with adherence to all other preventive measures for disease control. If voluntary vaccine uptake has failed to achieve the desired rates, mandatory policies should be considered, provided that benefits outweigh harm for HCWs, patients' welfare is enhanced, and fair rules and exemptions are defined. Decisions should be balanced, taking into consideration differences in diseases, vaccines, specific healthcare settings and HCW groups at high risk, as well as special conditions such as epidemics. For supporters of mandatory vaccination, all scientific, ethical, legal, and financial conditions have been met. Vaccination should thus be routine for HCWs as are standard precautions and hand washing. For the opponents of mandatory policies, it is preferable for higher uptake rates to be achieved through consensus rather than coercion, as coercive policies would bear the cost of conflict and mistrust, devalue HCWs and thus alienate important allies and have long-term detrimental effects.

Healthcare institutions have a duty to protect patients, avoid nosocomial spread of infection, keep working efficiently during outbreaks and meet the public's trust. The higher the immunity rates among HCWs, the better it is for themselves, their patients and the public. Hence there is a moral imperative for healthcare authorities to secure vaccination rates among HCWs that are as high as possible, by adopting the optimal policy. Recommendations for HCW vaccination issued in different countries are quite similar; in contrast, however, considerable differences are observed in the endorsement of mandatory policies, and policies that seem to work in the United States may not work in Europe and vice versa. It should be stressed that data on mandatory policies come mainly from the United States, thus conclusions may not be applicable to the rest of the world. What the optimal policy is may thus vary among countries and facilities: a 'one-fits-all' strategy seems not to exist.
Acknowledgements

Emmanouil Galanakis was at the ECDC on Sabbatical from the University of Crete, Greece.

Conflict of interest

None declared.

\section{Authors' contributions}

Emmanouil Galanakis contributed to the design and the discussion, and drafted and revised the manuscript. Andreas Jansen contributed to the design and the discussion and revised the manuscript. Pietro Luigi Lopalco contributed to the design and the discussion and revised the manuscript. Johan Giesecke contributed to the design and the discussion and revised the manuscript.

References

1. Bechini A, Tiscione E, Boccalini S, Levi M, Bonanni P. Acellular pertussis vaccine use in risk groups (adolescents, pregnant women, newborns and health care workers): a review of evidences and recommendations. Vaccine. 2012;30(35):517990.

http://dx.doi.org/10.1016/j.vaccine.2012.06.005 PMid:22709953

2. Mitchell R, Ogunremi T, Astrakianakis G, Bryce E, Gervais R, Gravel D, et al. Impact of the 2009 influenza A ( $\left.\mathrm{H}_{1} \mathrm{~N}_{1}\right)$ pandemic on Canadian health care workers: a survey on vaccination, illness, absenteeism, and personal protective equipment. Am J Infect Control. 2012;40(7):611-6.

http://dx.doi.org/10.1016/j.ajic.2012.01.011 PMid:22575285

3. Mulholland EK, Griffiths UK, Biellik R. Measles in the 21st century. N Engl J Med. 2012;366(19):1755-7. http://dx.doi.org/10.1056/NEJMp1202396 PMid:22571199

4. Backer H.Counterpoint: in favor of mandatory influenza vaccine for all health care workers. Clin Infect Dis. 2006;42(8):1144-7. http://dx.doi.org/10.1086/501463 PMid:16575733

5. Chor JS, Pada SK, Stephenson I, Goggins WB, Tambyah PA, Clarke TW, et al. Seasonal influenza vaccination predicts pandemic $\mathrm{H}_{1} \mathrm{~N}_{1}$ vaccination uptake among healthcare workers in three countries. Vaccine. 2011;29(43):7364-9. http://dx.doi.org/10.1016/j.vaccine.2011.07.079 PMid:21807048

6. Hofmann F, Ferracin C, Marsh G, Dumas R. Influenza vaccination of healthcare workers: a literature review of attitudes and beliefs. Infection. 2006;34(3):142-7. http://dx.doi.org/10.1007/s15010-006-5109-5 PMid:16804657

7. Lugo NR. Will carrots or sticks raise influenza immunization rates of health care personnel? Am J Infect Control. 2007;35(1):1-6.

http://dx.doi.org/10.1016/j.ajic.2006.10.004 PMid: 17276784

8. American Medical Association (AMA). Routine universal immunization of physicians for vaccine-preventable disease. CEJA Report 5-1-10. Chicago, IL: AMA. [Accessed 23 Aug 2013]. Available from: http://www.ama-assn.org/resources/doc/codemedical-ethics/9133a.pdf

9. Wynia MK. Mandating vaccination: what counts as a "mandate" in public health and when should they be used? Am J Bioeth. 2007;7(12):2-6. http://dx.doi.org/10.1080/15265160701795809 PMid:18098005

10. Poland GA, Tosh P, Jacobson RM. Requiring influenza vaccination for health care workers: seven truths we must accept. Vaccine. 2005;23(17-18):2251-5. http://dx.doi. org/10.1016/j.vaccine.2005.01.043 PMid: 15755605

11. Salgado CD, Giannetta ET, Hayden FG, Farr BM. Preventing nosocomial influenza by improving the vaccine acceptance rate of clinicians. Infect Control Hosp Epidemiol. 2004;25(11):923-8. http://dx.doi.org/10.1086/502321 PMid: 15566025

12. Weinstock DM, Eagan J, Malak SA, Rogers M, Wallace H, Kiehn TE, et al. Control of influenza $A$ on a bone marrow transplant 
unit. Infect Control Hosp Epidemiol. 2000;21(11):730-2. http://dx.doi.org/10.1086/501726

PMid:11089659

13. Gunson RN, Shouval D, Roggendorf M, Zaaijer H, Nicholas H, Holzmann $\mathrm{H}$, et al. Hepatitis $B$ virus (HBV) and hepatitis $C$ virus (HCV) infections in health care workers (HCWs): guidelines for prevention of transmission of HBV and HCV from HCW to patients. J Clin Virol. 2003;27(3):213-30. http://dx.doi.org/10.1016/S1386-6532(03)00087-8

14. DeStefano F, Verstraeten T, Chen RT. Hepatitis B vaccine and risk of multiple sclerosis. Expert Rev Vaccines. 2002;1(4):4616. http://dx.doi.org/10.1586/14760584.1.4.461 PMid:12901584

15. Demicheli V, Rivetti A, Debalini MG, Di Pietrantonj C. Vaccines for measles, mumps and rubella in children. Cochrane Database Syst Rev. 2012;2:CDo04407. PMid:22336803

16. Salmon DA, Proschan M, Forshee R, Gargiullo P, Bleser W, Burwen DR, et al. Association between GuillainBarré syndrome and influenza $\mathrm{A}\left(\mathrm{H}_{1} \mathrm{~N}_{1}\right) 2009$ monovalent inactivated vaccines in the USA: a meta-analysis. Lancet. 2013;381(9876):1461-8 http://dx.doi.org/10.1016/S0140-6736(12)62189-8

17. BurlsA, Jordan R, Barton P, Olowokure B, Wake B, Albon E, et al. Vaccinating healthcare workers against influenza to protect the vulnerable--is it a good use of healthcare resources? A systematic review of the evidence and an economic evaluation. Vaccine. 2006;24(19):4212-21. http://dx.doi.org/10.1016/j. vaccine.2005.12.043 PMid:16546308

18. Potter J, Stott DJ, Roberts MA, Elder AG, O’Donnell B, Knight $\mathrm{PV}$, et al. Influenza vaccination of health care workers in longterm-care hospitals reduces the mortality of elderly patients. J Infect Dis. 1997;175(1):1-6.

http://dx.doi.org/10.1093/infdis/175.1.1

PMid:8985189

19. Carman WF, Elder AG, Wallace LA, McAulay K, Walker A, Murray $G D$, et al. Effects of influenza vaccination of health-care workers on mortality of elderly people in long-term care: a randomised controlled trial. Lancet. 2000;355(9198):93-7. http://dx.doi.org/10.1016/S0140-6736(99)05190-9

20. Hayward AC, Harling R, Wetten S, Johnson AM, Munro S, Smedley J, et al. Effectiveness of an influenza vaccine programme for care home staff to prevent death, morbidity, and health service use among residents: cluster randomised controlled trial. BMJ. 2006;333(7581):1241. http://dx.doi. org/10.1136/bmj.39010.581354.55 PMid:17142257. PMCid:PMC1702427

21. Lemaitre M, Meret T, Rothan-Tondeur M, Belmin J, Lejonc JL, Luquel $L$, et al. Effect of influenza vaccination of nursing home staff on mortality of residents: a cluster-randomized trial. J Am Geriatr Soc. 2009;57(9):1580-6.

http://dx.doi.org/10.1111/j.1532-5415.2009.02402.x PMid:19682118

22. Thomas RE, Jefferson T, Lasserson TJ. Influenza vaccination for healthcare workers who care for people aged 60 or older living in long-term care institutions. Cochrane Database Syst Rev. 2013;7:CD005187.

PMid:23881655

23. Talbot TR. Improving rates of influenza vaccination among healthcare workers: educate; motivate; mandate? Infect Control Hosp Epidemiol. 2008;29(2):107-10. http://dx.doi. org/10.1086/527573 PMid:18179364

24. Babcock HM, Gemeinhart N, Jones M, Dunagan WC, Woeltje KF. Mandatory influenza vaccination of health care workers: translating policy to practice. Clin Infect Dis. 2010;50(4):45964 . http://dx.doi.org/10.1086/650752 PMid:20064039

25. Huynh S, Poduska P, Mallozzi T, Culler F. Mandatory influenza vaccination of health care workers: a first-year success implementation by a community health care system. Am J Infect Control. 2012;40(8):771-3. http://dx.doi.org/10.1016/j.ajic.2011.10.011 PMid:22325484

26. van Delden JJ, Ashcroft R, Dawson A, Marckmann G, Upshur $\mathrm{R}$, Verweij MF. The ethics of mandatory vaccination against influenza for health care workers. Vaccine. 2008;26(44):55626. http://dx.doi.org/10.1016/j.vaccine.2008.08.002 PMid:18722495

27. Ziegler E, Roth C, Wreghitt T. Prevalence of measles susceptibility among health care workers in a UK hospital. Does the UK need to introduce a measles policy for its health care workers? Occup Med (Lond). 2003;53(6):398-402. http://dx.doi.org/10.1093/occmed/kqg077

28. Hope K, Butler M, Massey PD, Cashman P, Durrheim DN, Stephenson J, et al. Pertussis vaccination in child care workers: room for improvement in coverage, policy and practice. BMC Pediatr. 2012;12:98. http://dx.doi.org/10.1186/1471-2431-12-98 PMid:22794120. PMCid:PMC3411446

29. Johansen K, Nicoll A, Ciancio BC, Kramarz P. Pandemic influenza $A\left(\mathrm{H}_{1} \mathrm{~N}_{1}\right) 2009$ vaccines in the European Union. Euro Surveill. 2009;14(41):pii=19361. Available from: http://www. eurosurveillance.org/ViewArticle.aspx?Articleld=19361 PMid:19883538

30. Rakita RM, Hagar BA, Crome P, Lammert JK. Mandatory influenza vaccination of healthcare workers: a 5-year study. Infect Control Hosp Epidemiol. 2010;31(9):881-8. http://dx.doi.org/10.1086/656210 PMid:20653445

31. Caplan A. Health workers must get flu shot or quit. Breaking bioethics on NBCNEWS.com. 8 Oct 2009. [Accessed 25 Aug 2013]. Available from: http://www.msnbc.msn.com/ id/33210502/ns/health-health_care/

32. Isaacs D, Leask J. Should influenza immunisation be mandatory for healthcare workers? No. BMJ. 2008;337:a2140. http://dx.doi.org/10.1136/bmj.a2140 PMid:18957465

33. Maltezou HC, Wicker S, Borg M, Heininger U, Puro V, Theodoridou $M$, et al. Vaccination policies for health-care workers in acute health-care facilities in Europe. Vaccine. 2011;29(51):9557-62.

http://dx.doi.org/10.1016/j.vaccine.2011.09.076

PMid:21964058

34. Palmore TN, Vandersluis JP, Morris J, Michelin A, Ruprecht LM, Schmitt JM, et al. A successful mandatory influenza vaccination campaign using an innovative electronic tracking system. Infect Control Hosp Epidemiol. 2009;30(12):1137-42. http://dx.doi.org/10.1086/648084 PMid:19860562

35. Poland GA, Ofstead CL, Tucker SJ, Beebe TJ. Receptivity to mandatory influenza vaccination policies for healthcare workers among registered nurses working on inpatient units. Infect Control Hosp Epidemiol. 2008;29(2):170-3. http://dx.doi.org/10.1086/526432 PMid:18179373

36. Tilburt JC, Mueller PS, Ottenberg AL, Poland GA, Koenig BA.Facing the challenges of influenza in healthcare settings: the ethical rationale for mandatory seasonal influenza vaccination and its implications for future pandemics. Vaccine. 2008;26Suppl 4:D27-30. http://dx.doi.org/10.1016/j.vaccine.2008.07.068 PMid:19230155 